\title{
Effects of forage source and forage particle size as a free-choice provision on growth performance, rumen fermentation, and behavior of dairy calves fed texturized starters
}

\author{
H. Omidi-Mirzaei, ${ }^{*}$ A. Azarfar, ${ }^{* 1}$ M. Mirzaei,† A. Kiani, ${ }^{,}$and M. H. Ghaffarił ${ }^{1,2}$ \\ *Department of Animal Science, Faculty of Agriculture, Lorestan University, PO Box 465, Khorramabad, Iran 44316-68151 \\ †Department of Animal Science, Faculty of Agriculture and Natural Resources, Arak University, Arak 38156-88349, Iran \\ ‡Department of Agricultural, Food and Nutritional Science, University of Alberta, Edmonton T6G 2P5, Canada
}

\begin{abstract}
We investigated the interactive effects of forage source and forage particle size (PS) as a free-choice provision on growth performance, rumen fermentation, and behavior of dairy calves fed texturized starters. Forty-eight Holstein calves ( $42 \pm 3 \mathrm{~kg}$ of body weight) were randomly assigned ( $\mathrm{n}=12$ calves per treatment) in a $2 \times 2$ factorial arrangement of treatments with the factors of forage source [alfalfa hay $(\mathrm{AH})$ and wheat straw (WS)] and forage PS [(AH: medium $=1.96 \mathrm{~mm}$ or long $=3.93 \mathrm{~mm}$ ) and (WS: medium $=2.03 \mathrm{~mm}$ or long $=4.10 \mathrm{~mm}$ ), as geometric mean diameters]. The treatments were (1) AH with medium PS (AH-MPS), (2) AH with long PS (AH-LPS), (3) WS with medium PS (WS-MPS), and (4) WS with long PS (WS-LPS). Regardless of forage PS, the preweaning starter intake, dry matter intake, metabolizable energy intake, weaning body weight, and forage intake were greater for $\mathrm{AH}$ calves than WS calves. Average daily gain, average daily gain/metabolizable energy intake, feed efficiency, and final body weight of the calves did not differ among groups. An interaction of forage source and forage PS influenced acetate, propionate, and acetate-to-propionate ratio in the rumen on $\mathrm{d} 35$, with the greatest acetate proportion and acetate-to-propionate ratio, but the least propionate proportion for AH-MPS calves than the other calves. The total volatile fatty acid concentration and the rumen proportions of propionate $(\mathrm{d}$ 70), butyrate (d 35), and valerate (d 35) were greater in AH-MPS calves than in AH-LPS calves. Calves fed $\mathrm{AH}$ had greater total volatile fatty acid concentration (d 35 and 70) and propionate proportion (d 70), but lesser ruminal proportions of butyrate (d 35 and 70),

\footnotetext{
Received October 14, 2017.

Accepted December 22, 2017.

${ }^{1}$ Corresponding authors: arash.azarfar@gmail.com and morteza1@

${ }^{2}$ Current address: Institute of Animal Science, Physiology and
} uni-bonn.de Hygiene Unit, University of Bonn, 53111 Bonn, Germany.
\end{abstract}

valerate (d 35 and 70), and acetate-to-propionate ratio (d 70) compared with calves fed WS. The ruminal valerate proportion (d 70) was greatest in WS-MPS calves than the other calves. An interaction of forage source and forage PS influenced preweaning standing time and starter eating time, with the least standing time for WS-MPS calves and the greatest eating starter time for AH-LPS calves. Calves fed AH spent less time for rumination, but devoted more time to non-nutritive oral behaviors than WS calves. Calves fed forage with long PS spent more time for rumination, eating forage, and spent less time lying and non-nutritive oral behaviors than medium PS. In conclusion, forage source and PS interacted, affecting behavior and rumen fermentation when calves were fed texturized starters. In addition, a desirable ruminal $\mathrm{pH}$ in dairy calves can be obtained with texturized starters.

Key words: calf, forage, texturized, particle size

\section{INTRODUCTION}

Considerable evidence exists in the literature that provision of forage can improve growth performance (Castells et al., 2012; Overvest et al., 2016; Imani et al., 2017), feed efficiency (Coverdale et al., 2004), rumen fermentation (Beiranvand et al., 2014; Mirzaei et al., 2015), and feeding behavior (EbnAli et al., 2016; Hosseini et al., 2016) of young calves fed ground starter feeds, although gut-fill could confound the results on weight gain from dietary forage intake (Khan et al., 2011). Studies showed that dairy calves could benefit from some dietary forage to maintain abrasion in their rumen and prevent abnormalities in the rumen epithelium (Greenwood et al., 1997), especially if the starter diet does not have an adequate particle size (PS). For example, feeding starters containing fine particles in mash form or processed in a pelleted form has triggered rapid ruminal acid production from fermentation of carbohydrates (Laarman et al., 2012), reduced ruminal pH (Laarman and Oba, 2011), and impaired 
rumen epithelial development (Greenwood et al., 1997). Previously, Terré et al. (2013) reported that forage provision rather than an increase in fiber content of the starter feed could improve pelleted starter intake and calf performance around weaning, and supplemental forage right after weaning is necessary to enhance calf performance. Moreover, Terré et al. (2015) showed that provision of straw to dairy calves promoted starter intake, regardless of the physical form of starter diets (pelleted or texturized forms). However, the literature on the effects of different physical forms of starter feed on calf performance is inconclusive and the discrepancies among studies could be due to differences in forage source (Imani et al., 2017), variations in physical and chemical structure of starter diets (Khan et al., 2016), or the PS of calf starters among the studies.

Feeding a forage source of adequate PS is thought to be required for dairy calves to promote chewing activity and saliva secretion, which elevate ruminal $\mathrm{pH}$ (Laarman and Oba, 2011; Nemati et al., 2015) and promote rumen health (Mirzaei et al., 2015). The results of a recent meta-analysis showed that forage provision to dairy calves had a beneficial effect on growth performance, but its effects can be modulated by forage source (Imani et al., 2017). It is known that the type of forage can influence a ground starter feed intake (Castells et al., 2012) and calf performance (Movahedi et al., 2017). This is likely because different forage have different nutrient compositions with varying effects on ruminating behavior (Castells et al., 2012) and feeding patterns (Miller-Cushon et al., 2013), which mainly influences buffering capacity in the rumen (Plaizier et al., 2008). These results suggest that if forage provision affects growth performance of dairy calves, it is worth investigating how changes in forage type and PS can improve the health and performance of calves during the transition from liquid to solid feed.

It has been demonstrated that the forage PS may also influence the effective fiber requirement of dairy calves. Nemati et al. (2015) found that increasing PS of alfalfa hay $(\mathbf{A H})$ from fine $(1 \mathrm{~mm}$, as a geometric mean) to medium (3 $\mathrm{mm}$, as a geometric mean) can improve calf performance and reduce their nonnutritive oral behaviors (NNOB) when calves were fed finely ground starter feeds. Mirzaei et al. (2015) also showed that the physical effectiveness of $\mathrm{AH}$ on performance and rumen development of dairy calves fed finely ground starters were affected by forage level, as the long PS of $\mathrm{AH}$ (5.04 mm as a geometric mean) rather than the medium PS of AH $(2.92 \mathrm{~mm}$, as a geometric mean) increased starter intake and weaning weight at $8 \%$ inclusion rate. Recently, Suarez-Mena et al. (2016) reported that increasing the PS of starter by changing the PS of straw (from about 3.04 to $12.7 \mathrm{~mm}$, as a geometric mean, at a $5 \%$ inclusion rate) resulted in minimal changes in ruminal fermentation and had no effect on rumen development parameters of dairy calves. The requirement for forage source is dependent on several factors, including diet ingredient composition and physical form of starter feeds. To our knowledge, limited information is available on how changes in PS and source of supplemental dietary forage might influence the growth performance of dairy calves fed starters in a textured form.

We tested the hypothesis that the effects of different forage sources on calf performance would be dependent on the PS of forage when offered as a free-choice provision. Therefore, 2 types of forage $[\mathrm{AH}$ and wheat straw (WS)] were provided with 2 PS (medium vs. long) to investigate their interactions on starter intake, growth performance, rumen fermentation, and behavior of dairy calves fed texturized starters during pre- and postweaning.

\section{MATERIALS AND METHODS}

\section{Animals, Management, and Treatments}

The current study was carried out from September 2016 to November 2016 on a local dairy farm (Goldasht-Nemone Agri. Animal Production Co., Isfahan, Iran) according to the guidelines of Iranian Council of Animal Care (1995). Air temperature and relative humidity data were obtained from the daily reports released by the Meteorological Network Station at NajafAbad (Isfahan, Iran). The average daily temperature was $18^{\circ} \mathrm{C}$ (range $=15-22^{\circ} \mathrm{C}$ ) and the relative humidity was $38.9 \%$ (range $=26-48 \%$ ) for the study period. A total of 48 Holstein calves ( $42 \pm 3 \mathrm{~kg}$ of BW) were blocked by sex and randomly assigned to 1 of the 4 dietary treatments $(\mathrm{n}=12$ calves, 6 male and 6 female calves per treatment) in a $2 \times 2$ factorial arrangement. Two forage sources (AH and WS) and forage PS (AH: medium $=1.96 \mathrm{~mm}$ or long $=3.93 \mathrm{~mm}$, WS: medium $=2.03 \mathrm{~mm}$ or long $=4.10 \mathrm{~mm}$; as geometric means) as a free-choice provision were used in dietary treatments of (1) AH with medium PS (AH-MPS), (2) AH with long PS (AH-LPS), (3) WS with medium PS (WSMPS), and (4) WS with long PS (WS-LPS).

Calves were separated from their dams immediately after birth, weighed, and moved to a naturally ventilated barn with individual pens $(1.2 \times 2.5 \mathrm{~m})$ bedded with sawdust, which was renewed every other day. The calves received $2.5 \mathrm{~L}$ of colostrum within $1.5 \mathrm{~h}$ of life and another $2.5 \mathrm{~L} 12 \mathrm{~h}$ later. From the second feeding time until d 3 of life, all calves received colostrum and transition milk. The quality of colostrum was measured with a digital Brix refractometer (PAL-1, Atago Co. 
Table 1. Ingredients, chemical composition, and particle size distribution of the starter feed

\begin{tabular}{|c|c|}
\hline Item & $\begin{array}{c}\text { Texturized } \\
\text { starter }\end{array}$ \\
\hline \multicolumn{2}{|l|}{ Ingredient ( $\%$ of DM basis) } \\
\hline Steam-rolled barley & 19.00 \\
\hline Steam-flaked corn & 40.50 \\
\hline Soybean meal $^{1}$ & 24.30 \\
\hline Pishgam premix ${ }^{1,2}$ & 14.40 \\
\hline Salt $^{1}$ & 0.50 \\
\hline Calcium carbonate $^{1}$ & 1.30 \\
\hline \multicolumn{2}{|l|}{ Chemical composition } \\
\hline $\mathrm{DM}(\mathrm{g} / \mathrm{kg}$ of $\mathrm{DM})$ & 90.00 \\
\hline $\mathrm{CP}(\mathrm{g} / \mathrm{kg}$ of $\mathrm{DM})$ & 21.91 \\
\hline ME (Mcal/kg) & 2.96 \\
\hline $\mathrm{NE}_{\mathrm{G}}(\mathrm{Mcal} / \mathrm{kg})$ & 1.34 \\
\hline $\mathrm{NDF}(\mathrm{g} / \mathrm{kg}$ of $\mathrm{DM})$ & 17.5 \\
\hline $\mathrm{ADF}(\mathrm{g} / \mathrm{kg}$ of $\mathrm{DM})$ & 11.0 \\
\hline $\mathrm{NFC}^{3}(\mathrm{~g} / \mathrm{kg}$ of $\mathrm{DM})$ & 52.0 \\
\hline Ether extract $(\mathrm{g} / \mathrm{kg}$ of $\mathrm{DM})$ & 3.50 \\
\hline $\mathrm{Ca}^{4}(\mathrm{~g} / \mathrm{kg}$ of DM) & 0.80 \\
\hline $\mathrm{P}^{4}(\mathrm{~g} / \mathrm{kg}$ of $\mathrm{DM})$ & 0.48 \\
\hline \multicolumn{2}{|c|}{ Particles retained on the sieve $(\mathrm{g} / \mathrm{kg}$, mean $\pm \mathrm{SD})$} \\
\hline $4.75 \mathrm{~mm}$ & $20.4 \pm 1.5$ \\
\hline $2.36 \mathrm{~mm}$ & $70.4 \pm 1.9$ \\
\hline $1.18 \mathrm{~mm}$ & $3.8 \pm 0.3$ \\
\hline $0.6 \mathrm{~mm}$ & $2.7 \pm 0.3$ \\
\hline $0.3 \mathrm{~mm}$ & $2.0 \pm 0.2$ \\
\hline $0.15 \mathrm{~mm}$ & $0.6 \pm 0.3$ \\
\hline Pan & $0.0 \pm 0.0$ \\
\hline $\mathrm{GMPL}^{5}(\mathrm{~mm})$ & $2.40 \pm 0.00$ \\
\hline
\end{tabular}

${ }^{1}$ All these ingredients were pelleted.

${ }^{2}$ Contained per $\mathrm{kg}$ of supplement (unless noted): $\mathrm{DM}=93 \%, \mathrm{CP}=$ $29 \%$, fat $=6.5 \%, \mathrm{ME}=2.31 \mathrm{Mcal}, \mathrm{NE}_{\mathrm{G}}=0.85 \mathrm{Mcal}, \mathrm{NDF}=17.5 \%$, $\mathrm{Ca}=0.65 \%, P=0.77 \%, \mathrm{NFC}=29 \%, \mathrm{Mg}(\mathrm{g})=2, \mathrm{~K}(\mathrm{~g})=0.99, \mathrm{Na}$ $(\mathrm{g})=1.6, \mathrm{Cl}(\mathrm{mg} / \mathrm{kg})=0.1, \mathrm{Co}(\mathrm{mg} / \mathrm{kg})=23, \mathrm{Mn}(\mathrm{mg} / \mathrm{kg})=43, \mathrm{Se}$ $(\mathrm{mg} / \mathrm{kg})=0.1, \mathrm{Zn}(\mathrm{mg} / \mathrm{kg})=43,12,000 \mathrm{IU}$ of vitamin $\mathrm{A}, 5,000 \mathrm{IU}$ of vitamin $\mathrm{D}$, and $100 \mathrm{IU}$ of vitamin $\mathrm{E}$.

${ }^{3}$ Nonfiber carbohydrate was calculated as DM $-(\mathrm{NDF}+\mathrm{CP}+$ ether extract + ash $)(\mathrm{NRC}, 2001)$.

${ }^{4}$ Estimated using the NRC (2001) model.

${ }^{5} \mathrm{GMPL}=$ geometric mean particle size; calculated as described by the American Society of Agricultural Engineers (ASAE, 1996; method S424.1).

Ltd., Bellevue, WA) and was discarded if it measured lesser than 22 on the Brix scale (Bielmann et al., 2010). If the dam produced colostrum of insufficient quality or quantity, frozen-thawed colostrum with sufficient quality was fed to the calf. Calves received $6 \mathrm{~L} / \mathrm{d}$ milk in steel buckets twice daily at 0800 and $1700 \mathrm{~h}$ from d 3 to 44 of the study, followed by feeding $3 \mathrm{~L} / \mathrm{d}$ milk until d 49 of the study. Calves were weaned on d 50 and remained in the study until d 70 of the study. All calves had ad libitum access to starter, forage, and water (via nipple drinkers) throughout the study. The nutrient compositions of the texturized starter are given in Table 1. The chemical composition of some ingredients (i.e., corn, barley, soybean meal, AH, WS) and whole milk are presented in Table 2 .

Before the experiment, forages ( $\mathrm{AH}$ and WS) were prepared from the same source and chopped to obtain medium and long PS (Golchin Trasher Hay Co., Isfahan, Iran) and used throughout the trial. A Penn State particle separator (Nasco, Fort Atkinson, WI) equipped with 3 sieves $(19,8$, and $1.18 \mathrm{~mm})$ and a bottom pan was used to separate samples for particle size analysis into long $(>19 \mathrm{~mm})$, medium $(<19,>8 \mathrm{~mm})$, short $(<8,>1.18 \mathrm{~mm})$, and fine $(<1.18 \mathrm{~mm})$ fractions (Kononoff et al., 2003a; see Table 3 for distribution of particle sizes of forages). At least 6 representative samples of forages (AH and WS) were collected 3 times throughout the study from each PS (medium and long) and used to analyze their PS distribution. After separation with the Penn State particle separator, the DM of each separated fraction was determined by oven drying at $56^{\circ} \mathrm{C}$ for $48 \mathrm{~h}$. Geometric mean $\left(\mathrm{X}_{\mathrm{gm}}\right)$ of the starter was calculated as described by the American Society of Agricultural Engineers (ASAE, 1996; method S424.1). Offered feeds (starter and forages) were adjusted daily to achieve 5 to $10 \%$ orts (i.e., the portion of the starter not consumed over a 24 -h period); orts were collected and weighed daily at $0800 \mathrm{~h}$. The treatment of disease followed the standard operating procedures at the Goldasht-Nemone Agri. Animal Production Co., and sick calves were treated by a veterinarian accordingly.

\section{Sampling and Laboratory Analyses}

Individual starter intake, forage intake, and total DMI (milk, starter feed, and forage) were measured

Table 2. Mean ( \pm SD) chemical composition of corn, barley, soybean meal, alfalfa hay, wheat straw (\%), and whole milk (\%)

\begin{tabular}{|c|c|c|c|c|c|c|}
\hline Item & Corn grain & Barley grain & Soybean meal & Alfalfa hay & Wheat straw & Whole milk \\
\hline $\mathrm{CP}$ & $9.4 \pm 0.7$ & $12.4 \pm 0.6$ & $48.0 \pm 0.4$ & $14.5 \pm 0.8$ & $4.5 \pm 0.1$ & $25.6 \pm 1.1$ \\
\hline $\mathrm{ADF}$ & $3.4 \pm 0.6$ & $7.2 \pm 0.5$ & $10.0 \pm 0.4$ & $33.5 \pm 1.1$ & $49.1 \pm 0.1$ & ND \\
\hline Ash & $1.7 \pm 0.2$ & $2.9 \pm 1.9$ & $4.80 \pm 0.4$ & $6.6 \pm 0.2$ & $5.9 \pm 0.6$ & ND \\
\hline Starch & $74.3 \pm 0.4$ & $52.3 \pm 1.3$ & $2.1 \pm 0.3$ & ND & ND & ND \\
\hline
\end{tabular}

${ }^{1} \mathrm{ND}=$ not determined. 
daily, and BW was recorded weekly using an electronic balance. Means of ADG and feed efficiency ( $\mathrm{kg}$ of BW gain $/ \mathrm{kg}$ of total DMI) were also calculated. Body measurements, including body length, wither height, heart girth, hip height, and hip width of the calves, were measured according to Lesmeister and Heinrichs (2004) on d 3, at weaning (d 50), and at the end of the study (d 70).

Feed samples were collected weekly throughout the experiment and stored at $-18^{\circ} \mathrm{C}$ pending chemical analysis. Subsamples of feeds and refusals were mixed thoroughly, dried at $56^{\circ} \mathrm{C}$ for $2 \mathrm{~d}$ in a forced-air oven, and ground to pass a through a 1-mm screen using a Wiley mill (Ogaw Seiki Co. Ltd., Tokyo, Japan) before chemical analyses for DM content (method 934.01; AOAC, 1990), ether extract (AOAC, 1990; method 920.39), CP (method 988.05; AOAC, 1990), ADF (AOAC, 1990: method 973.18), and NDF contents using heat-stable $\alpha$-amylase $(100 \mu \mathrm{L} / 0.5 \mathrm{~g}$ of the sample) with sodium sulfite (Van Soest et al., 1991). Milk samples were analyzed for DM, CP, fat, and lactose content by Milkoscan (Foss Electric, Hillerød, Denmark; AOAC, 1990).

Rumen fluid was collected at d 35 and 70 by a stomach tube fitted to a vacuum pump at $3 \mathrm{~h}$ postfeeding; the first $50 \mathrm{~mL}$ was discarded to avoid saliva contamination. The $\mathrm{pH}$ of the original rumen fluid sample was measured using a $\mathrm{pH}$ meter calibrated before each reading (HI 8318; Hanna Instruments, Cluj-Napoca, Romania). Rumen contents were squeezed through 4 layers of cheesecloth, and $8 \mathrm{~mL}$ of the rumen fluid was immediately acidified with $2 \mathrm{~mL}$ of $25 \%$ metaphosphoric acid and stored at $-20^{\circ} \mathrm{C}$ pending VFA analysis. Rumen concentrations of VFA were measured by GC (model CP-9002; Chrompack, Middelburg, the Netherlands) fitted with a 50-m (0.32-mm i.d.) silica-fused column (CP-Wax Chrompack Capillary Column; Varian, Palo Alto, CA), with crotonic acid (1:7, vol/vol) as an internal standard, as described by Bal et al. (2000). Helium was used as the carrier gas, and initial and final oven temperatures were 55 and $196^{\circ} \mathrm{C}$, respectively. The detector and injector temperatures were set at $251^{\circ} \mathrm{C}$.
Behavioral data were monitored by direct observations of all calves every 5 min for standing, lying, eating starter feed, eating forage, ruminating, and NNOB (when the animal licked any surface, tongue rolling, or sawdust consumption) and recorded as the total time (min) devoted to each behavior on wk 5, 6, 7, 8, 9, and 10 over $7 \mathrm{~h} / \mathrm{d}$. Calves were observed for $2 \mathrm{~h}$ before the milk feeding and $5 \mathrm{~h}$ immediately after the morning milk feeding during the preweaning week. During the postweaning week, the calves were observed for $2 \mathrm{~h}$ before and for $5 \mathrm{~h}$ after the solid feeds were offered. Thus, the total time for observing the behavior of each calf was equal to $42 \mathrm{~h}$ ( $21 \mathrm{~h}$ before and $21 \mathrm{~h}$ after weaning).

\section{Statistical Analyses}

Data were analyzed separately for the preweaning (from d 3-50 of the study), postweaning (from $d$ 51-70 of the study), and the overall (from d 1-70 of the study) periods. Statistical analyses were performed using PROC MIXED in SAS (version 9.3; SAS Inst. Inc., Cary, NC), with the individual calf as experimental unit; starter intake, forage intake, DMI, ADG, feed efficiency, and ME intake data were statistically analyzed as repeated measures, with period (day or week) as the repeated variable using the model

$$
\begin{aligned}
& Y_{i j k l}=\mu+F_{i}+P_{j}+T_{k}+(F \times T)_{i k}+(P \times T)_{j k} \\
& +(F \times P)_{i j}+(F \times P \times T)_{i j k}+\beta\left(X_{i}-X\right)+\varepsilon_{i j k l},
\end{aligned}
$$

in which $Y$ is the dependent variable; $\mu$ is the overall mean; $F_{i}$ is the effect of forage source; $P_{j}$ is the effect of forage PS; $T_{k}$ is the effect of period; $(F \times T)_{i j}$ is the interaction between forage source and period; $(P \times T)_{j k}$ is the interaction between forage PS and period; $(F \times$ $P)_{i j}$ is the interaction between forage source and forage PS; $(F \times P \times T)_{i j k}$ is the tripartite effect of forage source, forage PS, and period; $\beta\left(X_{i}-X\right)$ is the covariate variable (for $\mathrm{BW}$ and skeletal growth, the initial values were considered as covariates); and $\varepsilon_{i j k l}$ is the

\begin{tabular}{|c|c|c|c|c|}
\hline \multirow[b]{2}{*}{ Item $^{1}$} & \multicolumn{2}{|c|}{ Alfalfa hay } & \multicolumn{2}{|c|}{ Wheat straw } \\
\hline & Long & Medium & Long & Medium \\
\hline Long particles & $6.83 \pm 0.08$ & 00.0 & $6.11 \pm 0.06$ & 00.0 \\
\hline Medium particles & $34.36 \pm 1.02$ & $8.96 \pm 1.05$ & $30.60 \pm 0.92$ & $9.52 \pm 1.00$ \\
\hline Short particles & $25.78 \pm 0.42$ & $41.79 \pm 0.71$ & $37.18 \pm 0.58$ & $42.86 \pm 0.64$ \\
\hline Fine particles & $33.03 \pm 0.88$ & $49.25 \pm 1.02$ & $26.12 \pm 0.94$ & $47.62 \pm 1.04$ \\
\hline Geometric mean particle size (mm) & $3.93 \pm 0.99$ & $1.96 \pm 0.91$ & $4.10 \pm 0.92$ & $2.03 \pm 0.98$ \\
\hline
\end{tabular}

Table 3. Distribution of forage sources with medium and long particle sizes (\% DM retained on sieve; mean \pm SD)

${ }^{1}$ Particle separated, using a Penn State Particle Separator, into 4 fractions: long $(>19$ mm $)$, medium, $(<19,>8$ mm), short $(<8,>1.18$ mm), and fine $(<1.18 \mathrm{~mm})$. 
random residual error, assuming $N\left(0, \sigma^{2}\right)$, where $\sigma^{2}$ is variance. Before analyses, all data were screened for normality using the UNIVARIATE procedure of SAS. The autoregressive (order 1) covariance structure was the best fit for these data as determined by the lowest Akaike's information criterion. Rumen fermentation and structural growth variables were analyzed using a similar model but without the effect of time. Least squares means for treatment effects were separated using the PDIFF statement when the overall F-test was $P$ $\leq 0.05$. Trends were considered when $0.05<P \leq 0.10$.

\section{RESULTS}

\section{Intake and Growth Performance}

The results on DMI, starter intake, forage intake, ME intake, ADG, and feed efficiency are presented in Table 4. No interaction was detected between the forage source and forage PS or between the treatments and the period (3-way interactions) for DMI, starter feed intake, ME intake, $\mathrm{ADG}, \mathrm{ADG} / \mathrm{ME}$ intake, and feed efficiency. A 2-way interaction for preweaning DMI $(\mathrm{kg} / \mathrm{d}, P=0.01)$ and for forage intake as kilograms per day $(P=0.01)$ or a percent of $\mathrm{BW}(P<0.05)$ between forage source and the period were observed. A 2-way interaction for overall forage intake $(\mathrm{kg} / \mathrm{d}$ and $\%$ of BW, $P<0.05)$ and for preweaning ME intake $(P=$ $0.03)$ between forage PS and the period were observed.

Regardless of forage PS, preweaning DMI (1.28 vs. $1.18 \mathrm{~kg} / \mathrm{d} ; P=0.01$ ) was greater in calves fed $\mathrm{AH}$ than in those fed WS, although the overall and postweaning DMI was not affected by treatments. The postweaning and overall starter intake was not affected by dietary treatments, although the preweaning starter intake $(0.59$ vs. $0.51 \mathrm{~kg} / \mathrm{d} ; P=0.04)$ was greater in calves fed $\mathrm{AH}$ than in those fed WS, regardless of forage PS (Figure 1). Regardless of forage PS, the preweaning (67.7 vs. $39.1 \mathrm{~g} / \mathrm{d} ; P=0.01)$, postweaning (108.1 vs. $75.6 \mathrm{~g} / \mathrm{d} ; P=0.01)$, and overall $(84.4$ vs. $54.5 \mathrm{~g} / \mathrm{d} ; P=$ 0.01 ) forage intake were greater in calves fed $\mathrm{AH}$ than in those fed WS (Figure 2). Although the postweaning and overall ME intake were not affected by the treatments, preweaning ME intake (5.34 vs. $5.03 \mathrm{Mcal} / \mathrm{d} ; P$ $=0.02)$ was greater in calves fed AH than in those fed WS (Figure 3). Average daily gain, ADG/ME intake, and feed efficiency of the calves did not differ among the treatments.

Body measurements and BW data are presented in Table 5. No interaction was detected between the forage source and forage PS for BW, body length, wither height, heart girth, and hip height. An interaction of forage source and forage PS influenced hip width at d 70, with the greatest value for AH-LPS calves ( $P$
$=0.04$ ), although the differences were not biologically meaningful. Final BW, body length, hip height, and wither height of the calves did not differ among the treatments. Heart girth was greater in calves fed forage with medium PS than in those fed long PS (101 vs. 99 $\mathrm{cm} ; P=0.01)$. Regardless of forage PS, weaning BW $(79.3$ vs. $76.5 \mathrm{~kg} ; P=0.05)$ and final heart girth $(112$ vs. $109 \mathrm{~cm} ; P=0.03)$ were greater in calves fed $\mathrm{AH}$ than in those fed WS.

\section{Ruminal Characteristics}

Rumen fermentation data are presented in Table 6 . No interaction was detected between the forage source and forage PS for ruminal $\mathrm{pH}$, total VFA concentration, and the molar proportion of butyrate in the rumen. However, an interaction $(P=0.01)$ of forage source and forage PS influenced acetate, propionate, and acetateto-propionate ratio in the rumen on $\mathrm{d} 35$, with the greatest acetate proportion and acetate-to-propionate ratio but the least propionate proportion for observed AH-MPS calves.

The ruminal $\mathrm{pH}$ (d 35 and 70 of age), total VFA concentrations (d 35 of age), and the acetate proportion (d 70 of age) in the rumen did not differ across the treatments. The total VFA concentration (103.6 vs. $81.7 \mathrm{mmol} / \mathrm{L} ; P=0.01)$ and the molar proportion of propionate $(39.1$ vs. $36.8 \mathrm{~mol} / 100 \mathrm{~mol} ; P=0.03)$ in the rumen were greater in calves fed forage with medium PS than in those fed long PS on d 70 of age. The molar proportion of butyrate $(9.51$ vs. $7.72 \mathrm{~mol} / 100 \mathrm{~mol} ; P$ $=0.01)$ and valerate $(4.17$ vs. $3.38 \mathrm{~mol} / 100 \mathrm{~mol} ; P=$ $0.04)$ in the rumen were greater in calves fed forage with medium PS than in those fed long PS at d 35 of age. However, the acetate-to-propionate ratio (d 70, 1.41 vs. $1.29 \mathrm{~mol} / 100 \mathrm{~mol} ; P=0.08)$ in the rumen tended to be greater in calves fed forage with long PS than in those fed medium PS.

The total VFA concentration $(98.2$ vs. $87.1 \mathrm{mmol} / \mathrm{L}$; $P=0.04)$ and the molar proportion of propionate $(40.3$ vs. $35.6 \mathrm{~mol} / 100 \mathrm{~mol} ; P=0.01)$ in the rumen were greater in calves fed $\mathrm{AH}$ than calves fed WS on d 70 of age. The molar proportion of butyrate $(9.50$ vs. 7.73 $\mathrm{mol} / 100 \mathrm{~mol}, P=0.01)$ and valerate (4.19 vs. 3.37 $\mathrm{mol} / 100 \mathrm{~mol}, P=0.03)$ in the rumen were greater in calves fed WS than in those fed AH on d 35 of age. The molar proportion of butyrate (9.85 vs. $6.79 \mathrm{~mol} / 100$ mol, $P=0.01)$ in the rumen was greater in calves fed WS than in those fed $\mathrm{AH}$ on $\mathrm{d} 70$ of age. The acetateto-propionate ratio in the rumen was greater (1.44 vs. $1.26, P=0.01)$ in calves fed WS compared with those fed $\mathrm{AH}$ on $\mathrm{d} 70$ of age. The rumen molar proportion of valerate was greater $(P=0.01)$ in WS-MPS calves than in the other calves on $\mathrm{d} 70$ of age. 


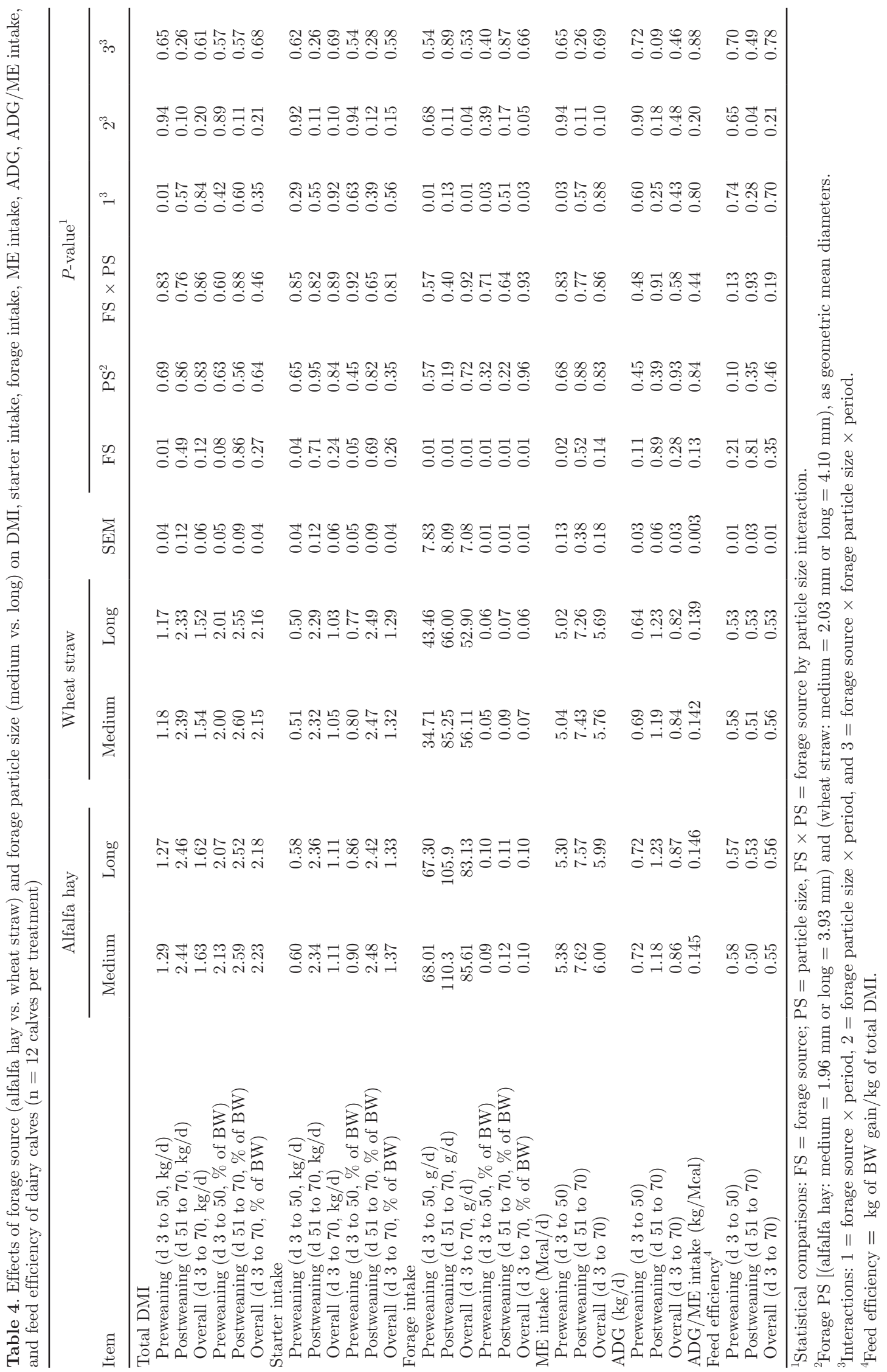




\section{Animal Behavior}

Table 7 presents the total time devoted to each behavior of the experimental animals conducted during 3 wk before and 3 wk after weaning. No interaction was detected between the forage source and forage PS for the time devoted to lying, ruminating, eating forage, and NNOB. An interaction of forage source and forage PS influenced standing time $(P=0.03)$ and starter eating time $(P=0.01)$ during the preweaning period, with the least standing time for WS-MPS calves and greatest starter eating time for AH-LPS calves.

Calves fed forage with medium PS devoted greater time to lying than calves fed forage with long PS during the preweaning (197 vs. $164 \mathrm{~min} / 7 \mathrm{~h}, P=0.01$ ) and overall (189 vs. $164 \mathrm{~min} / 7 \mathrm{~h}, P=0.02$ ) periods. Calves fed forage with long PS had greater ruminating time compared with calves fed forage with medium

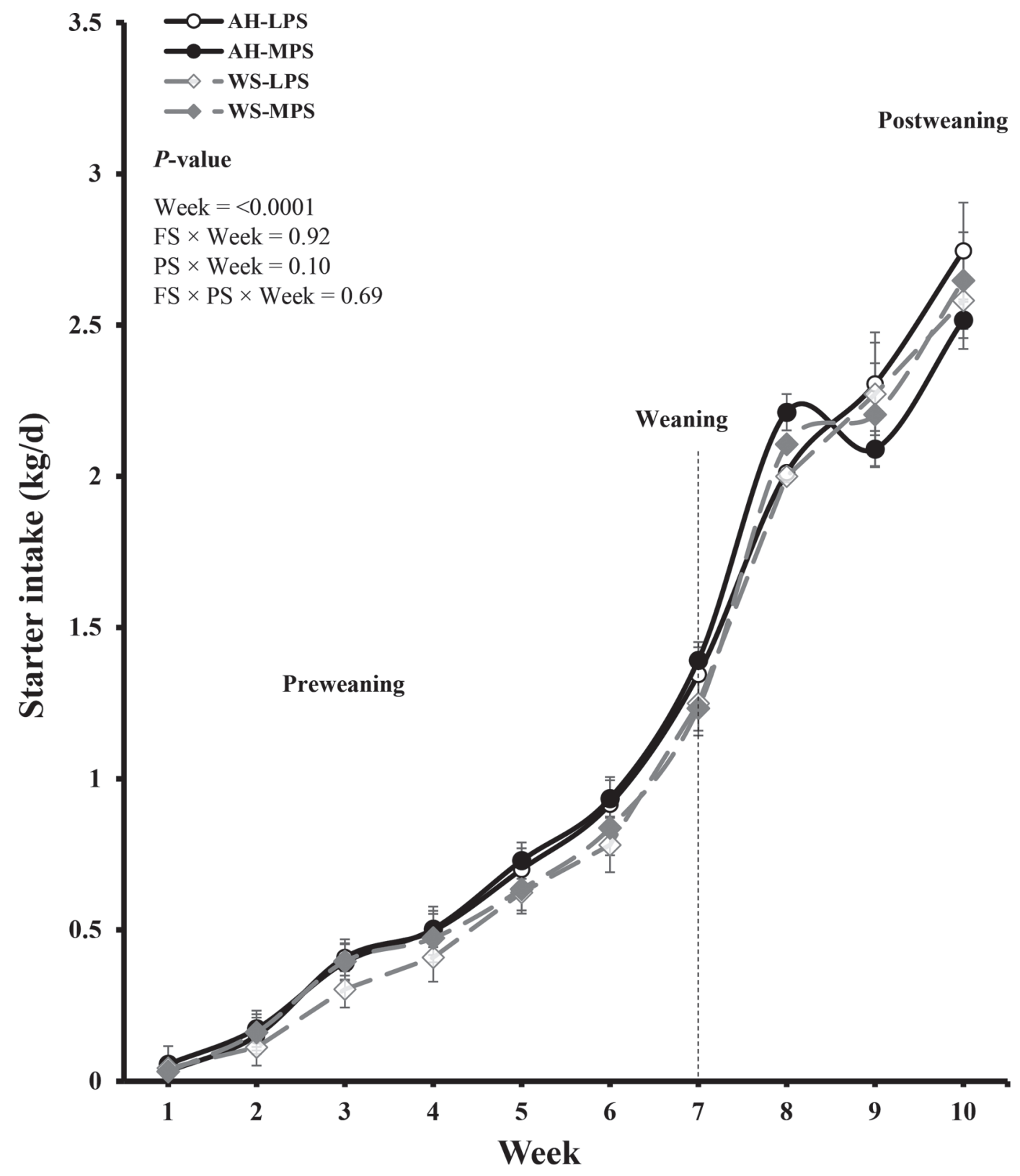

Figure 1. The effect of forage source [alfalfa hay $(\mathrm{AH})$ and wheat straw $(\mathrm{WS})]$ and forage particle size $[(\mathrm{AH}:$ medium $=1.96 \mathrm{~mm}$ or long $=3.93 \mathrm{~mm}$ ) and (WS: medium $=2.03 \mathrm{~mm}$ or long $=4.10 \mathrm{~mm}$ ), as geometric means] as a free-choice provision on starter intake of dairy calves ( $\mathrm{n}=12$ calves per treatment). Treatments were (1) AH with a medium particle size (AH-MPS), (2) AH with a long particle size (AH-LPS), (3) WS with a medium particle size (WS-MPS), and (4) WS with a long particle size (WS-LPS). Interactions: FS $\times$ Week $=$ forage source $\times$ period, PS $\times$ Week $=$ forage particle size $\times$ period, and FS $\times$ PS $\times$ Week $=$ forage source $\times$ forage particle size $\times$ period, respectively. Error bars indicate SE. 
PS during the preweaning $(74$ vs. $59 \mathrm{~min} / 7 \mathrm{~h}, P=$ 0.05 ), postweaning ( 88.5 vs. $75.0 \mathrm{~min} / 7 \mathrm{~h}, P=0.05$ ), and overall ( 81.0 vs. $67.0 \mathrm{~min} / 7 \mathrm{~h}, P=0.04)$ periods. Calves fed forage with long PS devoted greater time to eating forage compared with calves fed forage with medium PS during the preweaning ( 42.5 vs. $28.0 \mathrm{~min} / 7$ $\mathrm{h}, P=0.02)$ and overall $(31.0$ vs. $23.0 \mathrm{~min} / 7 \mathrm{~h}, P$ $=0.04)$ periods. Calves fed forage with medium PS devoted greater time to NNOB compared with calves fed forage with long PS during the preweaning (20.5 vs. $11.5 \mathrm{~min} / 7 \mathrm{~h}, P=0.01)$, postweaning (16.5 vs. 9.5 $\mathrm{min} / 7 \mathrm{~h}, P=0.02)$, and overall $(18.5$ vs. $11.0 \mathrm{~min} / 7 \mathrm{~h}$, $P=0.01)$ periods.

Calves fed WS spent greater time for ruminating compared with those fed $\mathrm{AH}$ during the preweaning (78.0 vs. $55.0 \mathrm{~min} / 7 \mathrm{~h}, P=0.01$ ), postweaning (87.5 vs. $76.0 \mathrm{~min} / 7 \mathrm{~h}, P=0.07)$, and overall ( 82.5 vs. 65.5 $\min / 7 \mathrm{~h}, P=0.02)$ periods. Moreover, calves fed $\mathrm{AH}$ spent more time performing NNOB compared with those fed WS during the postweaning (15 vs. $11 \mathrm{~min} / 7$

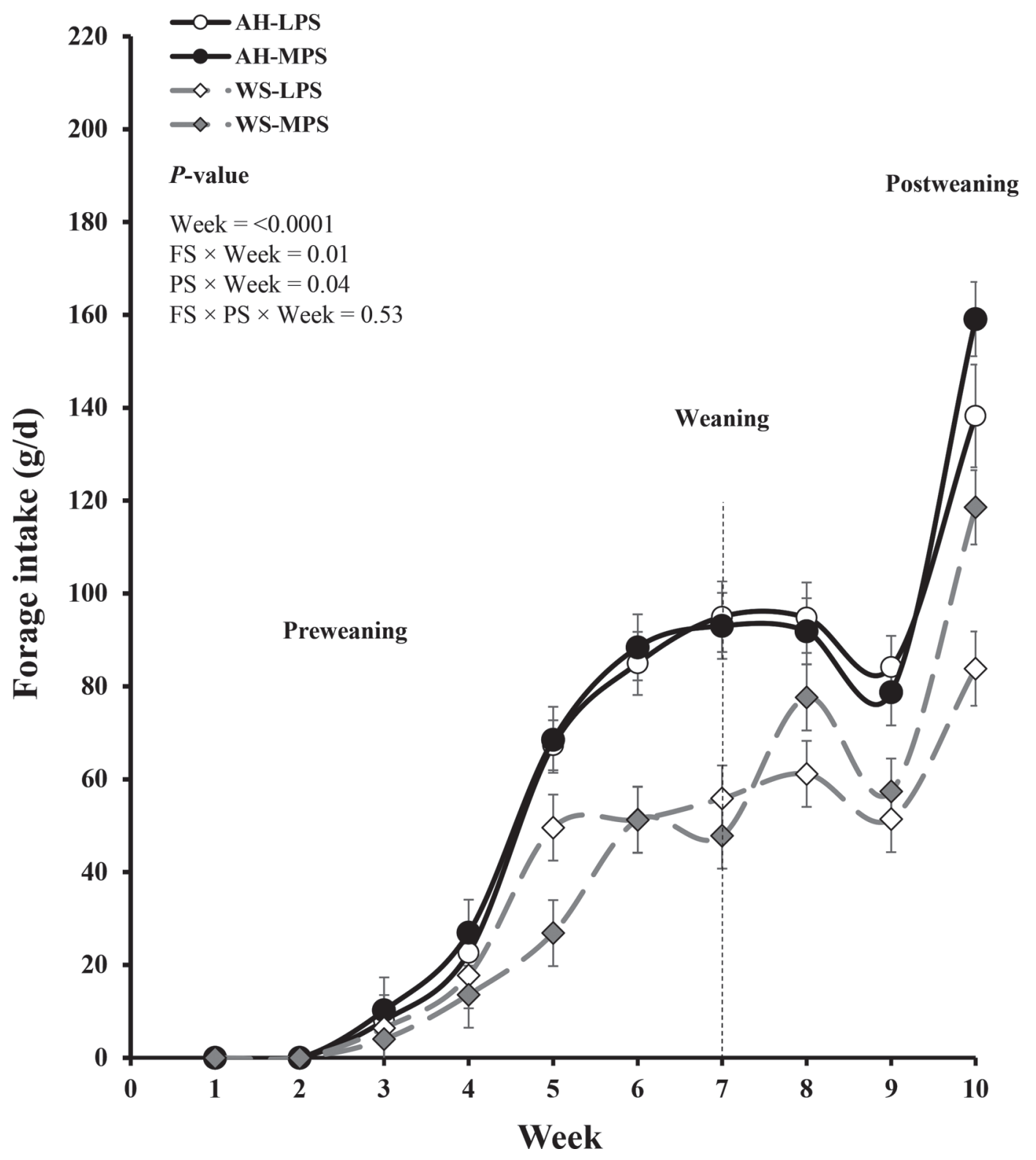

Figure 2. The effect of forage source [alfalfa hay $(\mathrm{AH})$ and wheat straw $(\mathrm{WS})]$ and forage particle size $[(\mathrm{AH}: \mathrm{medium}=1.96 \mathrm{~mm}$ or long $=3.93 \mathrm{~mm}$ ) and $($ WS: medium $=2.03 \mathrm{~mm}$ or long $=4.10 \mathrm{~mm}$ ), as geometric means] as a free-choice provision on forage intake of dairy calves ( $\mathrm{n}=12$ calves per treatment). Treatments were (1) AH with a medium particle size (AH-MPS), (2) AH with a long particle size (AH-LPS), (3) WS with a medium particle size (WS-MPS), and (4) WS with a long particle size (WS-LPS). Interactions: FS $\times$ Week $=$ forage source $\times$ period, PS $\times$ Week $=$ forage particle size $\times$ period, and FS $\times$ PS $\times$ Week $=$ forage source $\times$ forage particle size $\times$ period, respectively. Error bars indicate SE. 
h, $P=0.03$ ), and overall (16.5 vs. $13 \mathrm{~min} / 7 \mathrm{~h}, P=$ $0.08)$ periods.

\section{DISCUSSION}

\section{Intake and Growth Performance}

It is well known that the effects of forage provision to dairy calves on starter intake and growth performance depend on the forage level (Imani et al., 2017), forage source (Castells et al., 2012), and physical form of starter or forage PS (Nemati et al., 2015; Mirzaei et al., 2016) when calves were fed ground starter feeds. We investigated feed intake and growth performance in calves fed different sources of forages (AH and WS) that were fed with 2 PS (medium and long) as a freechoice provision along with a texturized starter feed. Studies investigating the effects of forage provision on

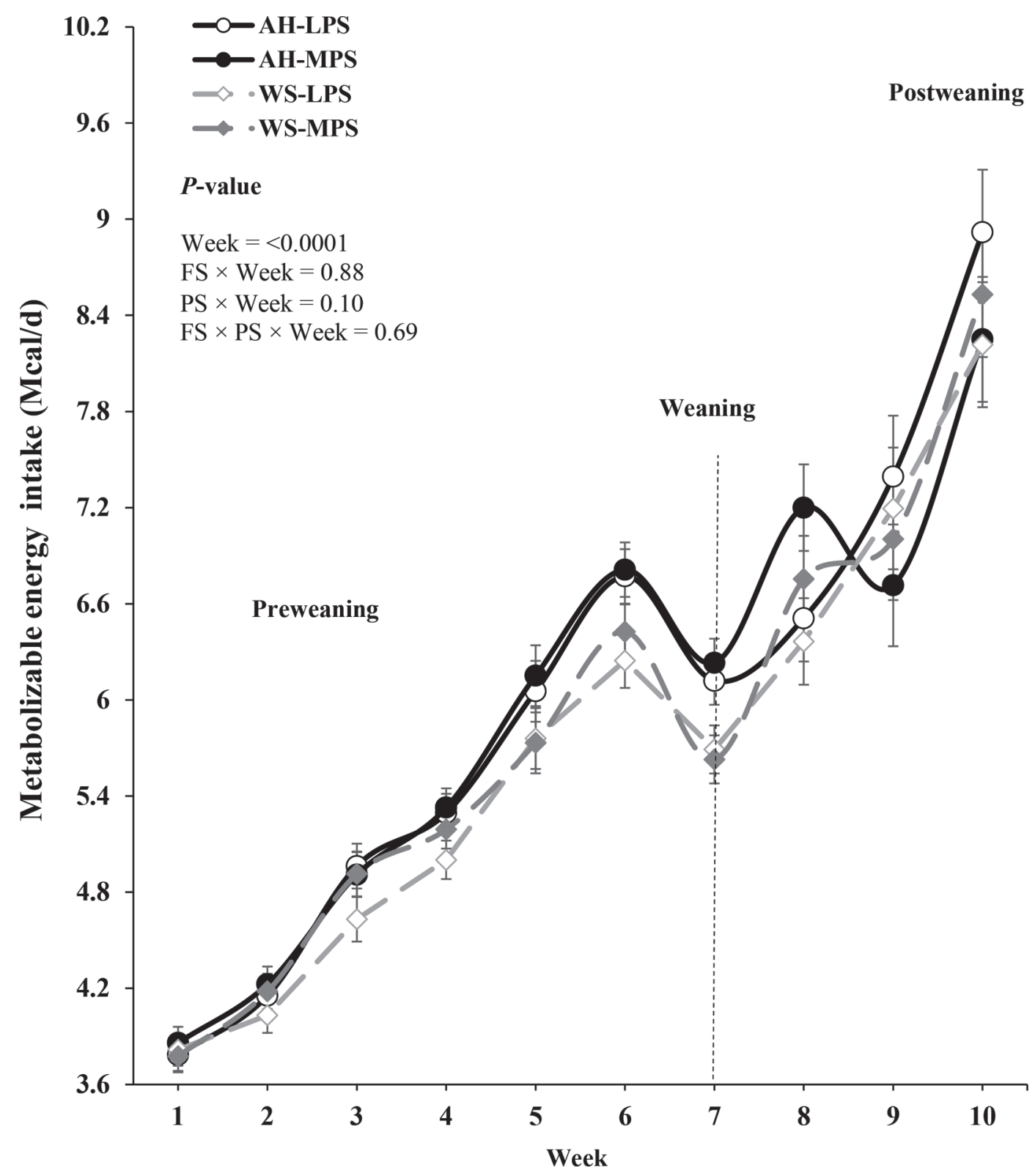

Figure 3. The effect of forage source [alfalfa hay $(\mathrm{AH})$ and wheat straw $(\mathrm{WS})]$ and forage particle size $[(\mathrm{AH}$ : medium $=1.96 \mathrm{~mm}$ or long $=$ $3.93 \mathrm{~mm}$ ) and (WS: medium $=2.03 \mathrm{~mm}$ or long $=4.10 \mathrm{~mm}$ ), as geometric means] as a free-choice provision on ME intake of dairy calves $(\mathrm{n}=12$ calves per treatment). Treatments were (1) AH with a medium particle size (AH-MPS), (2) AH with a long particle size (AH-LPS), (3) WS with a medium particle size (WS-MPS), and (4) WS with a long particle size (WS-LPS). Interactions: FS $\times$ Week $=$ forage source $\times$ period, PS $\times$ Week $=$ forage particle size $\times$ period, and FS $\times$ PS $\times$ Week $=$ forage source $\times$ forage particle size $\times$ period, respectively. Error bars indicate SE. 
Table 5. Effects of forage source (alfalfa hay vs. wheat straw) and forage particle size (medium vs. long) on BW and body measurements of dairy calves $(\mathrm{n}=12$ calves per treatment)

\begin{tabular}{|c|c|c|c|c|c|c|c|c|}
\hline Item & \multicolumn{2}{|c|}{ Alfalfa hay } & \multicolumn{2}{|c|}{ Wheat straw } & SEM & \multicolumn{3}{|c|}{$P$-value ${ }^{1}$} \\
\hline Initial (d 3) & 42.24 & 42.27 & 42.47 & 42.14 & 1.36 & 0.97 & 0.91 & 0.89 \\
\hline Weaning (d 50) & 78.94 & 79.71 & 78.42 & 74.52 & 1.40 & 0.05 & 0.27 & 0.10 \\
\hline Final (d 70) & 101.59 & 105.03 & 101.07 & 102.58 & 2.05 & 0.48 & 0.69 & 0.24 \\
\hline \multicolumn{9}{|l|}{ Body length $(\mathrm{cm})$} \\
\hline d 70 & 61.78 & 63.44 & 63.36 & 63.68 & 1.02 & 0.38 & 0.32 & 0.52 \\
\hline \multicolumn{9}{|c|}{ Wither height (cm) } \\
\hline d 3 & 79.15 & 78.69 & 79.96 & 78.01 & 0.95 & 0.70 & 0.11 & 0.22 \\
\hline d 50 & 89.26 & 87.89 & 89.52 & 89.68 & 0.88 & 0.25 & 0.54 & 0.39 \\
\hline d 70 & 92.77 & 93.25 & 92.73 & 92.42 & 0.96 & 0.63 & 0.91 & 0.67 \\
\hline \multicolumn{9}{|l|}{ Heart girth $(\mathrm{cm})$} \\
\hline d 3 & 83.56 & 83.37 & 84.89 & 82.98 & 1.01 & 0.68 & 0.17 & 0.23 \\
\hline d 70 & 21.29 & 21.83 & 21.64 & 21.25 & 0.21 & 0.61 & 0.72 & 0.04 \\
\hline \multicolumn{9}{|l|}{ Hip height $(\mathrm{cm})$} \\
\hline d 3 & 82.78 & 81.33 & 82.69 & 81.01 & 1.04 & 0.74 & 0.13 & 0.76 \\
\hline d 50 & 94.20 & 93.42 & 94.25 & 93.55 & 0.85 & 0.91 & 0.43 & 0.96 \\
\hline d 70 & 98.74 & 88.84 & 98.31 & 95.62 & 4.33 & 0.46 & 0.16 & 0.40 \\
\hline
\end{tabular}

${ }^{1}$ Statistical comparisons: FS $=$ forage source; PS $=$ particle size, FS $\times$ PS $=$ forage source by particle size interaction.

${ }^{2}$ Forage PS [(alfalfa hay: medium $=1.96 \mathrm{~mm}$ or long $=3.93 \mathrm{~mm}$ ) and (wheat straw: medium $=2.03 \mathrm{~mm}$ or long $=4.10 \mathrm{~mm}$ ), as geometric mean diameters.

Table 6. Effects of forage source (alfalfa hay vs. wheat straw) and forage particle size (medium vs. long) on rumen fermentation of dairy calves $(\mathrm{n}=12$ calves per treatment)

\begin{tabular}{|c|c|c|c|c|c|c|c|c|}
\hline Item & \multicolumn{2}{|c|}{ Alfalfa hay } & \multicolumn{2}{|c|}{ Wheat straw } & SEM & \multicolumn{3}{|c|}{$P$-value ${ }^{1}$} \\
\hline \multicolumn{9}{|c|}{$\overline{\text { Ruminal } \mathrm{pH}^{3}}$} \\
\hline d 35 & 6.12 & 6.10 & 6.15 & 6.37 & 0.14 & 0.43 & 0.61 & 0.53 \\
\hline d 70 & 5.94 & 5.97 & 5.96 & 5.98 & 0.05 & 0.92 & 0.85 & 0.97 \\
\hline \multicolumn{9}{|c|}{ Total VFA $(\mathrm{mmol} / \mathrm{L})$} \\
\hline d 35 & 90.2 & 94.4 & 69.2 & 83.0 & 9.01 & 0.10 & 0.65 & 0.32 \\
\hline \multicolumn{9}{|c|}{ Acetate } \\
\hline d 35 & 58.40 & 56.65 & 51.07 & 55.40 & 1.01 & 0.01 & 0.21 & 0.01 \\
\hline d 70 & 49.60 & 51.04 & 50.02 & 51.79 & 1.39 & 0.67 & 0.25 & 0.90 \\
\hline \multicolumn{9}{|c|}{ Propionate } \\
\hline d 35 & 28.68 & 34.04 & 34.45 & 31.68 & 1.17 & 0.16 & 0.28 & 0.01 \\
\hline d 70 & 41.47 & 39.19 & 36.66 & 34.46 & 0.97 & 0.01 & 0.03 & 0.96 \\
\hline \multicolumn{9}{|c|}{ Butyrate } \\
\hline \multicolumn{9}{|c|}{ Acetate:propionate } \\
\hline d 35 & 2.07 & 1.68 & 1.50 & 1.74 & 0.09 & 0.01 & 0.45 & 0.01 \\
\hline d 70 & 1.21 & 1.30 & 1.36 & 1.52 & 0.07 & 0.01 & 0.08 & 0.69 \\
\hline
\end{tabular}

${ }^{1}$ Statistical comparisons: $\mathrm{FS}=$ forage source; PS = particle size, $\mathrm{FS} \times \mathrm{PS}=$ forage source by particle size interaction.

${ }^{2}$ Forage PS [(alfalfa hay: medium $=1.96 \mathrm{~mm}$ or long $=3.93 \mathrm{~mm}$ ) and (wheat straw: medium $=2.03 \mathrm{~mm}$ or long $=4.10 \mathrm{~mm}$ ), as geometric mean diameters.

${ }^{3}$ Rumen $\mathrm{pH}$ was taken $3 \mathrm{~h}$ after feeding. 
Table 7. Effects of forage source (alfalfa hay vs. wheat straw) and forage particle size (medium vs. long) on the behavior of dairy calves ( $\mathrm{n}=$ 12 calves per treatment)

\begin{tabular}{|c|c|c|c|c|c|c|c|c|}
\hline Item $^{1}$ & \multicolumn{2}{|c|}{ Alfalfa hay } & \multicolumn{2}{|c|}{ Wheat straw } & SEM & \multicolumn{3}{|c|}{$P$-value ${ }^{2}$} \\
\hline \multicolumn{9}{|l|}{ Lying (min) } \\
\hline Postweaning (wk 8 to 10 ) & 186 & 169 & 177 & 161 & 10.3 & 0.47 & 0.13 & 0.93 \\
\hline Overall (wk 5 to 10 ) & 192 & 170 & 185 & 158 & 9.86 & 0.35 & 0.02 & 0.82 \\
\hline \multicolumn{9}{|l|}{ Standing (min) } \\
\hline Overall (wk 5 to 10$)$ & 113 & 107 & 93 & 116 & 8.04 & 0.49 & 0.28 & 0.08 \\
\hline \multicolumn{9}{|l|}{ Rumination $(\min )$} \\
\hline Preweaning (wk 5 to 7 ) & 48 & 62 & 70 & 86 & 7.07 & 0.01 & 0.05 & 0.94 \\
\hline Postweaning (wk 8 to 10 ) & 66 & 86 & 84 & 91 & 7.10 & 0.07 & 0.05 & 0.41 \\
\hline Overall (wk 5 to 10 ) & 57 & 74 & 77 & 88 & 6.63 & 0.02 & 0.04 & 0.66 \\
\hline \multicolumn{9}{|l|}{ Eating starter feed (min) } \\
\hline Preweaning (wk 5 to 7 ) & 11 & 22 & 18 & 12 & 2.94 & 0.73 & 0.37 & 0.01 \\
\hline Overall (wk 5 to 10$)$ & 22 & 32 & 24 & 30 & 3.44 & 0.98 & 0.04 & 0.46 \\
\hline \multicolumn{9}{|c|}{ Non-nutritive oral behaviors (min) } \\
\hline Preweaning (wk 5 to 7 ) & 21 & 13 & 20 & 10 & 2.16 & 0.36 & 0.01 & 0.54 \\
\hline Postweaning (wk 8 to 10 ) & 19 & 11 & 14 & 8 & 2.33 & 0.03 & 0.02 & 0.95 \\
\hline Overall (wk 5 to 10 ) & 20 & 13 & 17 & 9 & 2.15 & 0.08 & 0.01 & 0.73 \\
\hline
\end{tabular}

${ }^{1}$ Observations were conducted between 3 wk before and 3 wk after weaning by calves offered the experimental diets.

${ }^{2}$ Statistical comparisons: FS $=$ forage source; PS $=$ particle size, FS $\times$ PS = forage source by particle size interaction.

${ }^{3}$ Forage PS [(alfalfa hay: medium $=1.96 \mathrm{~mm}$ or long $=3.93 \mathrm{~mm}$ ) and (wheat straw: medium $=2.03 \mathrm{~mm}$ or long $=4.10 \mathrm{~mm}$ ), as geometric mean diameters.

calf performance have yielded inconsistent results, owing to factors such as forage PS (Mirzaei et al., 2015; Nemati et al., 2015) and forage sources (Imani et al., 2017).

Previous reports in the literature indicated that calves fed finely ground calf starter rations require forage fiber with sufficient particle length for effective rumination and healthy rumen development (Beiranvand et al., 2014; Nemati et al., 2015). Larger particles of AH were previously found to increase ground starter intake and weaning BW of dairy calves fed finely ground starters depending on forage levels (Mirzaei et al., 2015). Nemati et al. (2015) showed that the performance of dairy calves was improved by altering the PS of AH from fine $(1 \mathrm{~mm}$, as a geometric mean) to medium $(3 \mathrm{~mm}$, as a geometric mean) when calves had free access to finely ground starter feeds. However, the common perception is that an improvement in growth performance by forage feeding can be due to greater gut fill and increased weights of gastrointestinal tissues (Khan et al., 2011; Imani et al., 2017). Unlike previous research (Mirzaei et al., 2015; Nemati et al., 2015), in which PS of forage played a significant role on calf performance, in the current study dairy calves fed forage as free-choice provision had similar feed intake. Part of this discrepancy can be due to the forage offering method and the physical form of starter feeds. Moreover, the lack of an effect of forage PS on starter intake and ME intake could be the reason for the similar weight gain between medium and long PS diets in the current study.

Differences exist among the forage sources concerning their nutrient contents (i.e., CP, NFC, and NDF). Some studies recommended $\mathrm{AH}$ as the superior forage source for dairy calves (Imani et al., 2017) because of its high CP contents (Table 2) and palatability. However, another study did not recommend $\mathrm{AH}$ as a forage source because it was shown to reduce starter feed (NDF content 17.7\%) intake compared with barley straw in calves fed pelleted diets (Castells et al., 2012). In the current study, calves consumed greater amounts of $\mathrm{AH}$ compared with WS; the greater percentage of ADF and NDF (Table 2) in WS than AH may explain the lesser forage intake in calves fed WS as a free-choice provision. Similarly, Movahedi et al. (2017) reported a greater forage intake in calves fed $\mathrm{AH}$ than those fed WS when forage and ground starter feeds were offered separately. It is consistently stated that the voluntary intake of legume forages is greater than that of grass forages (Colburn et al., 1968; Moseley and Jones, 1979). However, Castells et al. (2012) suggested that greater 
forage intake may offset pelleted starter feed intake when the forage source is perceived as highly palatable.

The present results indicated that free-choice $\mathrm{AH}$ provision increased preweaning starter intake, DMI, and ME intake of calves fed texturized starter feeds; however, this increase did not improve ADG. The increase in DMI might be due to a greater flow rate out of the rumen of legumes compared with grasses (Moseley and Jones, 1979). Castells et al. (2013) also reported a greater ruminal passage rate for legumes than that of grasses in dairy calves, although gut fill could confound the results on weight gain from dietary forage intake (Khan et al., 2011). Part of this discrepancy between reports in the literature and our results may be related to the differences in the PS and physical forms of starters. Some previous studies reported a positive effect of $\mathrm{AH}$ on stimulating starter feed intake when $\mathrm{AH}$ was added to a finely ground starter diet (Beiranvand et al., 2014; Daneshvar et al., 2015; EbnAli et al., 2016), but a similar effect has not seen with texturized starter diets in dairy calves (Hill et al., 2008, 2010). The results of a recent meta-analysis (Imani et al., 2017) also showed that the increase in starter intake was greater for calves offered forages as a free-choice provision compared with those provided forages as a TMR through the weaning transition. Therefore, these results showed that providing free access to $\mathrm{AH}$ can be beneficial in improving starter intake even in calves fed starters containing large particle size.

\section{Ruminal Characteristics}

In the current study, ruminal $\mathrm{pH}$ ranged from 6.10 to 6.37 before weaning in calves offered texturized starter feed with free access to forage and ranged from 5.94 to 5.97 after weaning with no effects of forage source and PS on ruminal $\mathrm{pH}$. Previously, average rumen $\mathrm{pH}$ ranged from 5.25 to 5.89 in dairy calves fed a commercial texturized calf starter with or without chopped corn silage (Mirzaei et al., 2016), which was slightly less than our results. The ruminal $\mathrm{pH}$ of dairy calves did not differ from varying forage PS or source in the current study. Maktabi et al. (2016) observed similar ruminal $\mathrm{pH}$ levels in dairy calves fed finely ground starter feeds supplemented with different forage sources (AH vs. beet pulp). Our results regarding rumen $\mathrm{pH}$ are in line with the findings of Mirzaei et al. (2015), who reported similar ruminal $\mathrm{pH}$ in dairy calves fed $\mathrm{AH}$ as TMR (in mash form) with different PS (medium vs. long). We expected that increasing forage PS would affect ruminal $\mathrm{pH}$ of calves by increasing rumination and eating time, consequently increasing salivary secretion and ruminal buffering (van Ackeren et al., 2009). However, the increased rumination time caused by in- creasing forage PS in the present study had no positive effect on ruminal $\mathrm{pH}$; this finding may be because the calves in the current study consumed much less forage, most likely due to the physical form of the starter feed (textured). Previously, Terré et al. (2015) found lower ruminal $\mathrm{pH}$ in calves consuming a pelleted starter feed than calves consuming a texturized starter feed; however, a texturized starter feed had similar benefits on rumen $\mathrm{pH}$ as a pelleted starter feed supplemented with straw. It appears that a desirable rumen $\mathrm{pH}$ can be obtained with texturized starters and there is no need to supplement forage for this purpose, although it is difficult to conclude that with our study design.

In the current study, forage source interacted with forage PS to affect rumen fermentation. The proportion of acetate and the ratio of acetate to propionate were greater but propionate proportions in the rumen were lesser in AH-MPS calves compared with other calves during the preweaning period, which could be due to greater starter feed intake. The postweaning valerate proportions in the rumen were also greater in WS-MPS calves compared with other calves, which might be due to lower rate of valerate utilization by Megasphaera elsdenii bacteria in the rumen (Kung and Hession 1995). The PS of forage in the current study had significant effects on rumen fermentation parameters. The total ruminal VFA concentration and the molar proportions of individual VFA increased with decreasing forage PS from long to medium in our study, probably reflecting the extent of fermentation due to increasing the surface area available for a microbial fermentation in the rumen (Kononoff et al., 2003b).

In the current study, the increased total VFA concentration and the molar proportion of propionate in the rumen of calves offered $\mathrm{AH}$ on $\mathrm{d} 70$ could be attributed to the greater starter feed intake in $\mathrm{AH}$ compared with WS, which may have increased the supply of fermentable carbohydrates (starch and sugar) for the rumen bacteria (Wang et al., 2014). It is known that legumes have a higher buffering capacity than grasses (Waldo, 1986); thus, it could be suggested that AH may have been a better buffer than WS when a highstarch textured feed was offered, allowing calves to consume more starter feed. The previous report described a positive relationship between an increase in the rate of valerate utilization and microbial growth (Cline et al., 1958). The greater rumen valerate molar proportion observed in WS calves compared with $\mathrm{AH}$ calves might indicate a potentially reduced growth of Megasphaera elsdenii populations and decreased valerate utilization rate in the rumen. Similarly, Castells et al. (2013) also reported that valerate proportion in the rumen were lower in calves fed $\mathrm{AH}$ than in calves fed oat hay. Furthermore, the decrease in the rumen 
acetate-to-propionate ratio with $\mathrm{AH}$ was mainly due to an increase in rumen propionate molar proportion.

\section{Animal Behavior}

In recent years, some studies have evaluated the effects of forage provision during the weaning transition on the behavior of dairy calves. The effect of forage provision is likely to vary depending on several factors, including forage PS (Nemati et al., 2015) and forage source (Castells et al., 2012; Mirzaei et al., 2017). In the current study, forage source interacted with forage PS to affect the time of eating starter feed, which was longer for AH-LPS and WS-MPS calves and shorter for AH-MPS and WS-LPS calves during the preweaning period when forage was offered as a free-choice provision. Thus, when the forage PS was longer, calves spent more time in ruminating than eating starter feed as the NDF concentration increased in the forage, but when forage source was more palatable to calves, as with $\mathrm{AH}$, they spent more time in eating than ruminating. Furthermore, WS-MPS calves spent less time for standing during the preweaning period in the current study, indicating that these calves were less active.

The present results suggested that increasing forage PS plays an important role in calf behavior, where providing forage with long PS increased rumination time but reduced lying and NNOB of dairy calves fed the texturized starter feeds compared with medium PS. Nemati et al. (2015) observed that calves increased the amount of time spent ruminating and decreased their NNOB around weaning when the PS of AH increased from fine $(1 \mathrm{~mm})$ to medium $(3 \mathrm{~mm})$ as geometric means. Montoro et al. (2013) also reported that providing $10 \%$ coarsely chopped ( 3 to $4 \mathrm{~cm}$ ) grass hay to young calves fed a mixed ration containing (on a DM basis) $90 \%$ crumb starter feed reduced NNOB compared with offering finely ground $(2 \mathrm{~mm})$ grass hay. Longer forage eating time for calves fed forage with long PS during the pre- and postweaning periods were also expected because intakes of long forage particles require more eating time as a result of reduced eating rate (Nasrollahi et al., 2014). Therefore, our results suggest that increasing forage eating and rumination times by providing long PS of forage may help to reduce NNOB in dairy calves and improve calf behavior.

In the present study, forage source affected the behavior of dairy calves. The WS calves exhibited longer rumination times compared with $\mathrm{AH}$ calves during both pre- and postweaning periods, which may be associated with the relatively greater fiber content in WS. Provision of WS was associated with less postweaning NNOB compared with AH. We speculate that this activity relates to the increased time spent ruminating by the WS calves. This type of behavior is in line with the study of Castells et al. (2012), who found that calves fed barley straw devoted less time to perform NNOB and more time for ruminating during $8 \mathrm{~h}$ of observations over the weaning transition compared with those fed $\mathrm{AH}$.

\section{CONCLUSIONS}

The results from this study showed that the provision of chopped $\mathrm{AH}$ rather than WS increased preweaning intakes of starter, ME, and forage and weaning BW without improving ADG and final BW when a textured starter feed was offered. Our study shows that the effects of forage source on behavior and rumen fermentation are dependent upon the forage PS in dairy calves fed texturized starters. Feeding forage with longer PS increased time spent ruminating and eating forage but reduced time spent lying and NNOB compared with medium PS. In addition, calves fed AH devoted less time to ruminating but spent more time NNOB than WS calves. During the preweaning period, the greatest ruminal acetate proportion and acetate-to-propionate ratio but the lowest propionate proportion were observed in AH-MPS calves. Mainly, AH and medium PS increased the total VFA concentration and propionate proportion in the rumen compared with WS and long PS, respectively. Therefore, a better understanding of the effects of provision of grass and legume forages with different PS on intake and behavior of calves will aid in field management decisions to maximize the performance and behavior of young calves.

\section{ACKNOWLEDGMENTS}

The authors acknowledge Pishgam Damparvar Sepahan Co. (Isfahan, Iran) for financial support of this study. The authors thank Hamid Memar, Mohammad Moshtaghian, Mohsen Moazeni, Sadegh Kiani (staff of Goldasht-Nemone Agri. Animal Production Co., Isfahan, Iran), and Farzad Hashemzadeh (Isfahan University of Technology, Isfahan, Iran) for their help.

\section{REFERENCES}

AOAC. 1990. Official Methods of Analysis. 15th ed. Assoc. Off. Anal. Chem., Arlington, VA.

ASAE. 1996. S424.1. Method of determining and expressing particle size of chopped forage materials by sieving. Am. Soc. Agric. Eng., St. Joseph, MI.

Bal, M. A., R. D. Shaver, A. G. Jirovec, K. J. Shinners, and J. G. Coors. 2000. Crop processing and chop length of corn silage: Effects on intake, digestion, and milk production by dairy cows. J. Dairy Sci. 83:1264-1273. https://doi.org/10.3168/jds.S0022 -0302(00)74993-9.

Beiranvand, H., G. R. Ghorbani, M. Khorvash, A. Nabipour, M. Dehghan-Banadaky, A. Homayouni, and S. Kargar. 2014. Interactions 
of alfalfa hay and sodium propionate on dairy calf performance and rumen development. J. Dairy Sci. 97:2270-2280. https://doi .org/10.3168/jds.2012-6332.

Bielmann, V., J. Gillan, N. R. Perkins, A. L. Skidmore, S. Godden, and K. E. Leslie. 2010. An evaluation of Brix refractometry instruments for measurement of colostrum quality in dairy cattle. J. Dairy Sci. 93:3713-3721.

Castells, L., A. Bach, G. Araujo, C. Montoro, and M. Terré. 2012. Effect of different forage sources on performance and feeding behavior of Holstein calves. J. Dairy Sci. 95:286-293. https://doi.org/10 $.3168 /$ jds.2011-4405.

Castells, L., A. Bach, A. Aris, and M. Terré. 2013. Effects of forage provision to young calves on rumen fermentation and development of the gastrointestinal tract. J. Dairy Sci. 96:5226-5236. https:// doi.org/10.3168/jds.2012-6419.

Cline, J. H., T. V. Hershberger, and O. G. Bentley. 1958. Utilization and/or synthesis of valeric acid during the digestion of glucose, starch and cellulose by rumen micro-organism in vitro. J. Anim. Sci. 17:284-292. https://doi.org/10.2527/jas1958.172284x.

Colburn, M. W.. J. L. Evans, and C. H. Ramage. 1968. Ingestion control in growing ruminant animals by the components of cell-wall constituents. J. Dairy Sci. 51:1458-1464. https://doi.org/10.3168/ jds.S0022-0302(68)87212-1.

Coverdale, J. A., H. D. Tyler, J. D. Quigley III, and J. A. Brumm. 2004. Effect of various levels of forage and form of diet on rumen development and growth in calves. J. Dairy Sci. 87:2554-2562. https://doi.org/10.3168/jds.S0022-0302(04)73380-9.

Daneshvar, D., M. Khorvash, E. Ghasemi, A. H. Mahdavi, B. Moshiri, M. Mirzaei, A. Pezeshki, and M. H. Ghaffari. 2015. The effect of restricted milk feeding through conventional or step-down methods with or without forage provision in starter feed on performance of Holstein bull calves. J. Anim. Sci. 93:3979-3989. https:// doi.org/10.2527/jas.2014-8863.

EbnAli, A., M. Khorvash, G. R. Ghorbani, A. Nargeskhani, M. Malekkhahi, M. Mirzaei, A. Pezeshki, and M. H. Ghaffari. 2016. Effects of forage offering method on performance, rumen fermentation, nutrient digestibility, blood metabolites, and nutritional behavior in Holstein dairy calves. J. Anim. Physiol. Anim. Nutr. (Berl.) 100:820-827. https://doi.org/10.1111/jpn.12442.

Greenwood, R. H., J. L. Morrill, E. C. Titgemeyer, and G. A. Kennedy 1997. A new method of measuring diet abrasion and its effect on the development of the forestomach. J. Dairy Sci. 80:2534-2541. https://doi.org/10.3168/jds.S0022-0302(97)76207-6.

Hill, T. M., H. G. Bateman, J. M. Aldrich, and R. L. Schlotterbeck. 2008. Effects of the amount of chopped hay or cottonseed hulls in a textured calf starter on young calf performance. J. Dairy Sci. 91:2684-2693. https://doi.org/10.3168/jds.2007-0935.

Hill, T. M., H. G. Bateman, J. M. Aldrich, and R. L. Schlotterbeck. 2010. Roughage amount, source, and processing for diets fed to weaned dairy calves. Prof. Anim. Sci. 26:181-187. https://doi.org/ 10.15232/S1080-7446(15)30578-7.

Hosseini, S. M., G. R. Ghorbani, P. Rezamand, and M. Khorvash 2016. Determining optimum age of Holstein dairy calves when adding chopped alfalfa hay to meal starter diets based on measures of growth and performance. Animal 10:607-615. https://doi.org/ 10.1017/S1751731115002499.

Imani, M., M. Mirzaei, B. Baghbanzadeh-Nobari, and M. H. Ghaffari 2017. Effects of forage provision to dairy calves on growth performance and rumen fermentation: A meta-analysis and metaregression. J. Dairy Sci. 100:1136-1150. https://doi.org/10.3168/ jds.2016-11561.

Iranian Council of Animal Care. 1995. Guide to the Care and use of Experimental Animals. Isfahan University of Technology, Isfahan, Iran.

Khan, M. A., A. Bach, D. M. Weary, and M. A. G. von Keyserlingk. 2016. Invited review: Transitioning from milk to solid feed in dairy heifers. J. Dairy Sci. 99:885-902. https://doi.org/10.3168/jds.2015 $-9975$.

Khan, M. A., D. M. Weary, and M. A. G. von Keyserlingk. 2011. Hay intake improves performance and rumen development of calves fed higher quantities of milk. J. Dairy Sci. 94:3547-3553. https://doi .org/10.3168/jds.2010-3871.

Kononoff, P. J., A. H. Heinrichs, and D. R. Buckmaster. 2003a. Modification of the Penn State forage and total mixed ration particle separator and the effects of moisture content on its measurements. J. Dairy Sci. 86:1858-1863. https://doi.org/10.3168/jds.S0022 -0302(03)73773-4.

Kononoff, P. J., A. J. Heinrichs, and H. A. Lehman. 2003b. The effect of corn silage particle size on eating behavior, chewing activities, and rumen fermentation in lactating dairy cows. J. Dairy Sci. 86:3343-3353. https://doi.org/10.3168/jds.S0022-0302(03)73937 $-\mathrm{X}$

Kung, L., Jr., and A. O. Hession. 1995. Prevention in vitro lactate accumulation in ruminal fermentation with Megasphaera elsdenii. J. Anim. Sci. 73:250-256.

Laarman, A. H., and M. Oba. 2011. Short communication: Effect of calf starter on rumen $\mathrm{pH}$ of Holstein dairy calves at weaning. J. Dairy Sci. 94:5661-5664. https://doi.org/10.3168/jds.2011-4273.

Laarman, A. H., A. L. Ruiz-Sanchez, T. Sugino, L. L. Guan, and M. Oba. 2012. Effects of feeding a calf starter on molecular adaptations in the ruminal epithelium and liver of Holstein dairy calves. J. Dairy Sci. 95:2585-2594. https://doi.org/10.3168/jds.2011-4788.

Lesmeister, K. E., and A. J. Heinrichs. 2004. Effects of corn processing on growth characteristics, rumen development, and rumen parameters in neonatal dairy calves. J. Dairy Sci. 87:3439-3450. https:// doi.org/10.3168/jds.S0022-0302(04)73479-7.

Maktabi, H., E. Ghasemi, and M. Khorvash. 2016. Effects of substituting grain with forage or nonforage fiber source on growth performance, rumen fermentation, and chewing activity of dairy calves. Anim. Feed Sci. Technol. 221:70-78. https://doi.org/10.1016/j anifeedsci.2016.08.024.

Miller-Cushon, E. K., C. Montoro, A. Bach, and T. J. DeVries. 2013 Effect of early exposure to mixed rations differing in forage particle size on feed sorting of dairy calves. J. Dairy Sci. 96:3257-3264. https://doi.org/10.3168/jds.2012-6415.

Mirzaei, M., M. Khorvash, G. R. Ghorbani, M. Kazemi-Bonchenari, and M. H. Ghaffari. 2017. Growth performance, feeding behavior, and selected blood metabolites of Holstein dairy calves fed restricted amounts of milk: No interactions between sources of finely ground grain and forage provision. J. Dairy Sci. 100:1086-1094. https://doi.org/10.3168/jds.2016-11592.

Mirzaei, M., M. Khorvash, G. R. Ghorbani, M. Kazemi-Bonchenari, A. Riasi, A. Nabipour, and J. J. G. C. van den Borne. 2015. Effects of supplementation level and particle size of alfalfa hay on growth characteristics and rumen development in dairy calves. J. Anim. Physiol. Anim. Nutr. (Berl.) 99:553-564. https://doi.org/10.1111/ jpn.12229.

Mirzaei, M., M. Khorvash, G. R. Ghorbani, M. Kazemi-Bonchenari, A. Riasi, A. Soltani, B. Moshiri, and M. H. Ghaffari. 2016. Interactions between the physical form of starter (mashed versus textured) and corn silage provision on performance, rumen fermentation, and structural growth of Holstein calves. J. Anim. Sci. 94:678-686. https://doi.org/10.2527/jas.2015-9670.

Montoro, C., E. K. Miller-Cushon, T. J. DeVries, and A. Bach. 2013. Effect of physical form of forage on performance, feeding behavior, and digestibility of Holstein calves. J. Dairy Sci. 96:1117-1124. https://doi.org/10.3168/jds.2012-5731.

Moseley, G., and J. R. Jones. 1979. Some factors associated with the difference in nutritive value of artificially dried red clover and perennial ryegrass for sheep. Br. J. Nutr. 42:139-147. https://doi .org/10.1079/BJN19790098.

Movahedi, B., A. D. Foroozandeh, and P. Shakeri. 2017. Effects of different forage sources as a free-choice provision on the performance, nutrient digestibility, selected blood metabolites and structural growth of Holstein dairy calves. J. Anim. Physiol. Anim. Nutr. (Berl.) 101:293-301. https://doi.org/10.1111/jpn.12527.

Nasrollahi, S. M., G. R. Ghorbani, M. Khorvash, and W. Z. Yang. 2014. Effects of grain source and marginal change in lucerne hay particle size on feed sorting, eating behaviour, chewing activity, and milk production in mid-lactation Holstein dairy cows. J. 
Anim. Physiol. Anim. Nutr. (Berl.) 98:1110-1116. https://doi.org/ 10.1111/jpn.12185.

Nemati, M., H. Amanlou, M. Khorvash, B. Moshiri, M. Mirzaei, M. A. Khan, and M. H. Ghaffari. 2015. Rumen fermentation, blood metabolites, and growth performance of calves during transition from liquid to solid feed: Effects of dietary level and particle size of alfalfa hay. J. Dairy Sci. 98:7131-7141. https://doi.org/10.3168/ jds.2014-9144.

NRC. 2001. Nutrient Requirements of Dairy Cattle. 7th rev. ed. Natl. Acad. Press, Washington, DC.

Overvest, M. A., R. Bergeron, D. B. Haley, and T. J. DeVries. 2016. Effect of feed type and method of presentation on feeding behavior, intake, and growth of dairy calves fed a high level of milk. J. Dairy Sci. 99:317-327. https://doi.org/10.3168/jds.2015-9997.

Plaizier, J. C., D. O. Krause, G. N. Gozho, and B. W. McBride. 2008. Subacute ruminal acidosis in dairy cows: The physiological causes, incidence and consequences. Vet. J. 176:21-31. https://doi.org/10 $.1016 /$ j.tvjl.2007.12.016.

Suarez-Mena, F. X., A. J. Heinrichs, C. M. Jones, T. M. Hill, and J. D. Quigley. 2016. Straw particle size in calf starters: Effects on digestive system development and rumen fermentation. J. Dairy Sci. 99:341-353. https://doi.org/10.3168/jds.2015-9884.

Terré, M., L. Castells, M. A. Khan, and A. Bach. 2015. Interaction between the physical form of the starter feed and straw provision on growth performance of Holstein calves. J. Dairy Sci. 98:1101-1109. https://doi.org/10.3168/jds.2014-8151.

Terré, M., E. Pedrals, A. Dalmau, and A. Bach. 2013. What do preweaned and weaned calves need in the diet: A high fiber content or a forage source? J. Dairy Sci. 96:5217-5225. https://doi.org/10 $.3168 /$ jds.2012-6304.

van Ackeren, C., H. Steingaß, K. Hartung, R. Funk, and W. Drochner. 2009. Effect of roughage level in a total mixed ration on feed intake, ruminal fermentation patterns and chewing activity of early weaned calves with ad libitum access to grass hay. Anim. Feed Sci. Technol. 153:48-59. https://doi.org/10.1016/j.anifeedsci.2009 .05.009.

Van Soest, P. J., J. B. Robertson, and B. A. Lewis. 1991. Methods for dietary fiber, neutral detergent fiber nonstarch polysaccharide in relation to animal nutrition. J. Dairy Sci. 74:3583-3597. https:// doi.org/10.3168/jds.S0022-0302(91)78551-2.

Waldo, D. R. 1986. Effect of forage quality on intake and forage-concentrate interactions. J. Dairy Sci. 69:617-631. https://doi.org/10 .3168/jds.S0022-0302(86)80446-5.

Wang, B., S. Y. Mao, H. J. Yang, Y. M. Wu, J. K. Wang, S. L. Li, Z M. Shen, and J. X. Liu. 2014. Effects of alfalfa and cereal straw as a forage source on nutrient digestibility and lactation performance in lactating dairy cows. J. Dairy Sci. 97:7706-7715. https://doi .org/10.3168/jds.2014-7961. 